- FINANSE I PRAWO FINANSOWE.

- Journal of Finance and Financial Law •

Wrzesień/September 2017 • vol. 3(15): 65-79

http://dx.doi.org/10.18778/2391-6478.3.15.06

\title{
THE PROBLEMS OF CONSUMER'S PROTECTION IN THE FINANCIAL MARKET IN UKRAINE: EMPIRICAL RESEARCH
}

Sophia Lobozynska

Bank and Insurance Business Department

Ivan Franko L'viv National University

\begin{abstract}
The article presents the results of empirical research of rights protection of consumer of financial services in Ukraine. It revealed the scope and nature of the violations of the rights of financial services consumers, and the actions of the respondents for the protection of their rights. Special attention is focused on identifying the level of financial literacy of people and finding effective tools of consumer rights protection. The need for the development and adoption of the National Strategy for rights protection of consumers of financial services market and increasing of financial literacy were proved.
\end{abstract}

Keywords: financial consumer protection, financial literacy, financial regulators, out-of-court mechanisms of disputes resolution, National strategy.

JEL Class: D18. 


\section{INTRODUCTION}

The push to find new ways to protect the rights of consumers of financial services market has become global financial crisis of 2007-2008. This stimulated to large-scale applied research by international financial institutions and leading scientists to identify tools for elimination of violations of consumer rights in obtaining and use of financial services. Promptly respond to the crisis came from the European Parliament, which in 2008 conducted research on improving consumers level of education and awareness on financial products [Rutledge et al. 2010].

The Basel Committee together with the International Organization of Securities Commission and International Association of Insurance Supervisors conducted a research on customer suitability in the retail sale of financial products and services [Customer suitability..., 2008]. A series of studies was conducted under the aegis of the World Bank. In particular, in 2009 the World Bank has been conducting a study of Consumer Protection and Financial Literacy Lessons from Nine Country Studies [Rutledge 2010]. In 2012 the World Bank published Good Practices for Financial Consumer Protection in 2012 [Good Practices..., 2012].

In 2014 results of Global Survey on Consumer Protection and Financial Literacy (Oversight frameworks and practices in 114 economies) conducted by the World Bank in 2013, became available. This survey was prepared by the World Bank and other agencies to stimulate a discussion and help promote consensus on effective approaches in financial consumer protection supervision. [Global Survey on Consumer Protection..., 2014]. Study of the results of such research gives an opportunity to create national consumer protection systems that ensuring the rights of consumers of financial products and services and protecting them from fraud, losses, and market abuses. They also help properly organize national studies which form the basis for developing an effective policy of rights protection of consumers on financial services market.

The article aim is to measure the volume and determine the nature of the violations of rights of consumers of financial services in Ukraine, to determine the level of financial literacy and to provide recommendations on structure of effective financial consumer protection in order to achieve financial stability in the country in the long run.

\section{THE RESEARCH METHODOLOGY}

To assess the rights protection system for consumer of financial services and their level of financial competence in Ukraine we have chosen the empirical method of research - a questioning in writing. Questionnaire: „Rights protection 
of financial services consumers" was developed by the author of this scientific research. Questionnaire consists of 12 questions, grouped into three thematic blocks. The first block includes questions to identify respondent (determining the age, sex, level of education); the second block includes questions which could set the scales and categories of violations and respondent behavior on condition that rights were violated; the third block of questions aimed to identify the level of financial competence of people and to develop effective tools for protecting the consumer rights. The questionnaire was conducted in November 2016. In of the research participated 1500 respondents.

The questionnaire involved men and women aged from 18 years, consumers of banking services, living in L'viv and L'viv region. The largest part of respondents (54\%) belongs to the age group 26-55 years, which is economically active population. The smallest part of respondents is taken by 56+ age group. It makes only $8 \%$.Another criterion of identification of respondents was the differentiation them by gender. The survey involved more women $(57 \%)$ than men (43\%). Accoding to results of the servey, higher education have $45 \%$ of respondents, also very large part of respondents, namely $30 \%$ have incomplete higher education, $16 \%$ - secondary special education; 9\% of respondents have secondary education [Lobozynska 2016].

\section{ANALYSIS OF FINANCIAL CONSUMER PROTECTION IN UKRAINE}

Through research of rights protection of financial services consumers was important to find out whether the problem of violation of such rights exist and how often consumers face problems during obtaining financial products. In this order the respondents were asked to answer the question from the questionnaire ,Were your rights violated during receining the financial services". $24 \%$ of all respondents believe that during using the financial services their rights have been violated.

Figure 1 presents differentiation by age group of respondents. The largest share of violations of consumer rights in the financial market was recorded in the age group $56+(32 \%)$. In particular, by the results of the research we can conclude that with increasing of age of the respondents, the percentage of violation of their rights by financial institutions is growing, it can be explained by the longer time lag when assessing the relationship between consumers and financial business.

According to the respondents votes the large proportion of violations (29\%) of consumers rihts from financial institutions was observed in the age group 2655. The explanation for this can be assumption that respondents over 25 years old are more likely to use financial services, they are more involved in 
cooperation with financial institutions. They use more ofter innovative banking products, which are subject to higher risk, that is why consumer rights violations are recorded more frequently.

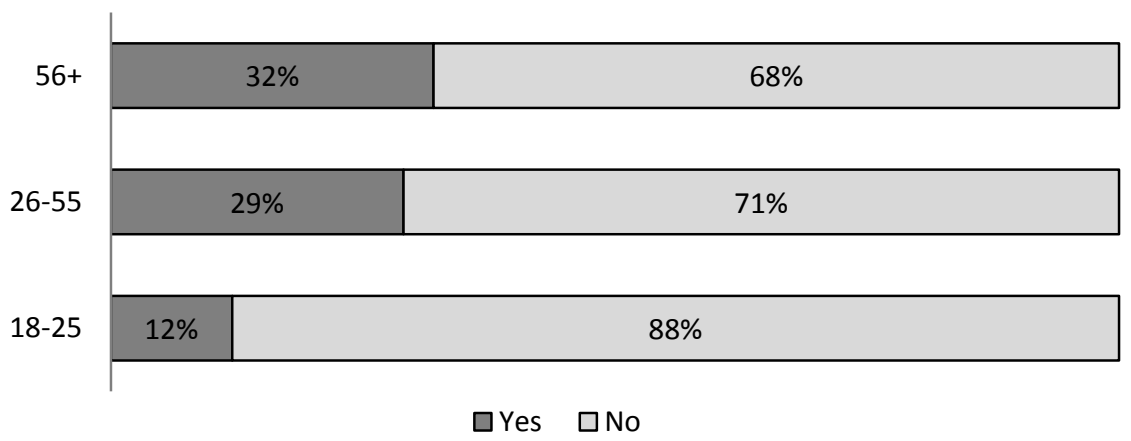

Figure 1. Have your rights been violated when you had received banking services? (according to age)

Source: S.M. Lobozynska, 2016, Report on the survey „Protection of consumers in financial services in Ukraine", November, 1,500 questionnaires.

In the group of $18-25$ were recorded the smallest part of violations $-12 \%$, indicating the limited behavior of such customers in financial services market due to lack of own savings, partial financial independence and low activity in financial processes.

Overall we believe that the share of violations is significant, which reduces the level of people's confidence in the financial market. Due to results of the public opinion poll in December 2016 by the Foundation for Democratic initiatives the distrust to banks is 73 , the National Bank of Ukraine $(-65 \%)$ [2016th: political results..., 2016]. According to the Global Competitiveness rating the stability of Ukrainian banking system the second consecutive year is the worst in the world. Thus, according to data from 2015-2016 by this criterion Ukrainian banking system ranked last, 140th place, and according to the new forecast for the years 2016-2017 - improved their positions by only two steps. [Radchuk 2017]. Under such conditions the strategic objectives of the legislative and executive bodies should become an effective mechanism to protect the customer rights of financial services as the foundation of formation the stable financial system, in which banks play a key role.

Using a questionnaire we found that the most consumers' rights are violated during obtaining credits, deposits and payment services. Figure 2 shows the proportion of violations that occurred when using specific financial transactions. The information is provided in terms of age groups of consumers. 


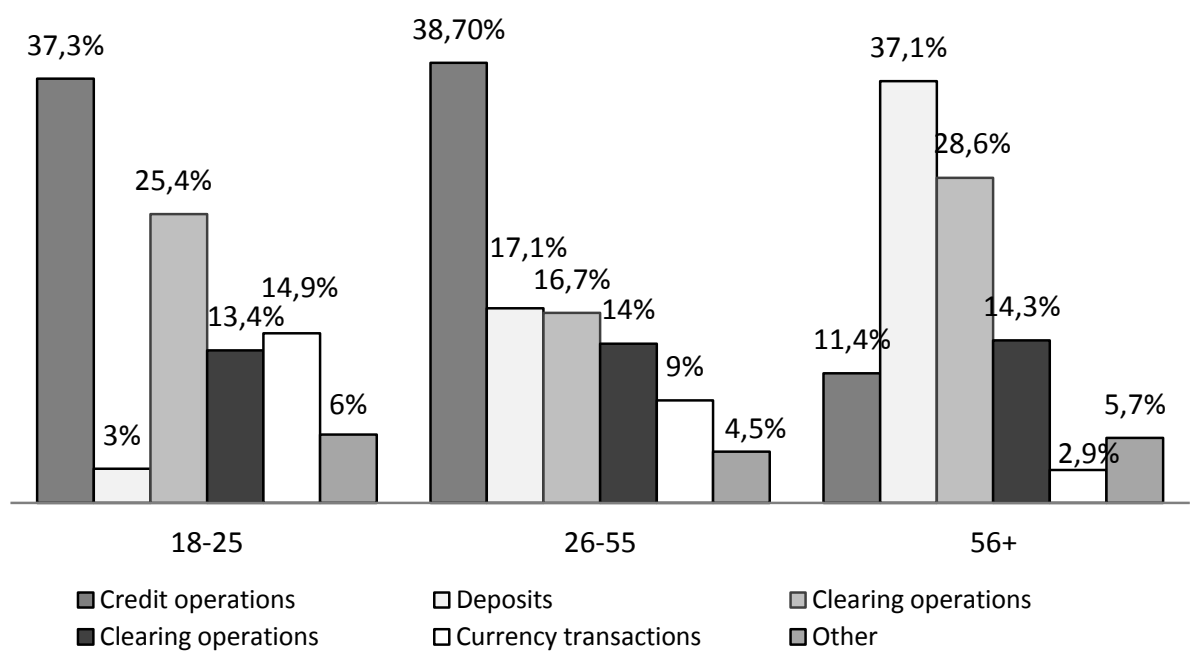

Figure 2. Shares of violations that occurred in obtaining financial services

Source: S.M. Lobozynska, 2016, Report on the survey „Protection of consumers in financial services in Ukraine", November, 1,500 questionnaires.

In the 18-25 age group rights violations happened the most during realization credit and payment operations. The smallest part of violations occurred at the time of deposit operations. In the 26-55 age group most violations observed at the time of credit and deposit operations, and the least at the time of foreign currency exchange. In the 56+ age group the most rights violations were made during realization deposit and payment transactions. In the category 56+ consumer rights are violated the least in making foreign currency exchange transactions.

Analyzing the survey data we discovered that exists especially acute problem of consumer rights protection from in the age group from 18 to 55 in the plane of credit operations $-38 \%$ out of all violations that have occurred with the respondents.

The most violations of rights of consumer of loaning services happen during conclusions of credit agreements. These agreements usually consist of many pages, they are printed in small type, contain a lot of information, which causes reluctance of borrowers to carefully familiarize themselves with the terms of the credit agreement, and later borrower calculate his financial losses from not fair interest rates and payments.

In Ukrainian banking practice we noted cases that in the consumer credit agreement banks left a right for themselves to unilaterally raise lending rates. For minor violations banks demanded early repayment of loans. 
In retail lending banks didn't inform about the total cost of the loan, but only about the obligation of payment of interest on the loan, not focusing on one-time and periodic commissions for credit support. Realizing among the public credit cards or payment cards with limits on loans, banks noted differentiated interest rates depending on the amount of the loan. The borrower, using small amounts of credit get used to the small size of the loan percent, and increasing the amount of loan he already did not remember the progressive increase in interest on larger amounts of borrowed funds. Additional financial losses have become an unpleasant surprise to the borrower. Therefore, it is important to develop model agreements of consumer credit. Contracts must be concluded maximum simplified for understanding. Agreements must be added with the information that would have contained a calculation of the full cost of the loan. In addition it is necessary on the legislative level to oblige banks to provide customers with instant access to information on 1) all transactions made by credit account (all transactions concerning the account for a specified period), 2) Interest charged for a specified period; 3) Fees charged for specified period Outstanding balance for credit. This problem in Ukraine could be solved with passage of the Law „On consumer credit”.

Banks should bear criminal responsibility for financial fraud related to the use of individuals date for their own fraudulent acts (including the use of passport data lending of straw bail, illegal usege guarantie obtained from individuals when lending to related parties, transfer information on borrowers to third parties, including collection companies, etc.). Repeatedly there were customer complaints on limit of their right to choose the insurance company for insurance assets transferred as collateral against loans.

Significant violations are happening during using banks deposit services. The most susceptible category of the population that felt abuses by financial institutions are persons aged from 56 years $(37.1 \%$ share of violations in the use of deposit transactions of total violations), for the age group 25-55 this share is $-17 \%$.

Exploring the deposit market we can resume that most consumers' rights were violated when banks refused customer on early funds withdrawal from the account of a fix date deposit, although this right has been specified in the deposit agreement. Banks in terms of a currency crisis refused to return customers deposit in foreign currency, while the amount was paid in terms of national currency.

Considering the significant bank bankruptcies in the years 2014-2016 the Fund Deposit Guarantee in time had paid compensatory payments to depositors of failed banks, but there were cases when investors got their money much later than was required by law during the activities of temporary administrations and liquidators. Moreover, the interests on overdue deposits after the introduction of temporary administration were not assessed. This led to 
additional financial losses of consumer. The rights of investors of foreign currency deposits and deposits over the guarantee amount (200 $000 \mathrm{UAH})$ are unprotected by two reasons: a significant depreciation of the national currency against foreign currencies and lack of DGF revenues from sales of assets of liquidated banks. Therefore, improvements are needed in area of law enforcement activities in terms of cooperation with the Fund Deposit Guarantee as to disclosure of fraud and corruption acts by owners and managers of banks deemed insolvent and also supervisory authorities (NBU officials and authorized persons DGF). Now, out of 400 allegations of committing criminal offenses, which were filed by the Fund on the owners and managers of insolvent banks, only two cases were ended with a guilty verdict [Statistics of $D G F \ldots, 2017$ ]. Thus, a reasonable and timely prosecution of people whose actions led to bankruptcy of banking institution will contribute to the preservation of assets of banks and increase the degree of protection of property rights of investors and creditors.

Evaluation of results of empirical research found that large portion violations happen during usage of payment services. In particular, in the age group $18-25$ this proportion is $25.4 \%$, in the $26-55$ group $-16.7 \%$, in the $56+$ group $-28.6 \%$. In particular, in most cases violations of consumer rights occur when they use payment cards. Thus, the challenge for cardholders is that banks set limits on withdrawals from ATMs depending on the bank in the range of $1500-6000$. There are also restrictions on the quantity of transactions - not more than 3 per day. According to the current banking law, banks can limit the amount of money per one day when withdrawing them from ATMs if this action is described in the contract and provided under condition that the customer must be informed of this in the manner prescribed in an agreement. However, Ukrainian banks often do not fix these conditions in the agreement and include there the so-called offer, i.e. issue so-called ,dynamic agreement”. This agreement includes the general rules and rules of using the payment card, but detailed daily limit values for possible withdrawal and rates for service point at the bank website, and not in the contract. The information on its website the bank can always change what allows limiting the amount of money that the owner of the card account can withdraw at an ATM in one day. These deficiencies undermine confidence in the banking system, negatively affect the progressive development of the payment cards market and to some extent hinder this development.

Thus, we can resume that in Ukraine at this stage the protection of rights of consumers of financial services is on rather low level, in addition, there are no clear signs of consistency, there is no unity of purpose to protect the rights of clients of financial institutions. Consumers under condition of absence 
of sufficient information do not know that their rights are violated, or they cannot prove it when dealing with litigation.

Research has proven that there is an extremely high proportion of consumers of financial services $(69 \%)$ who are aware of the need to deepen their knowledge in accordance to protect their rights (Fig. 3).

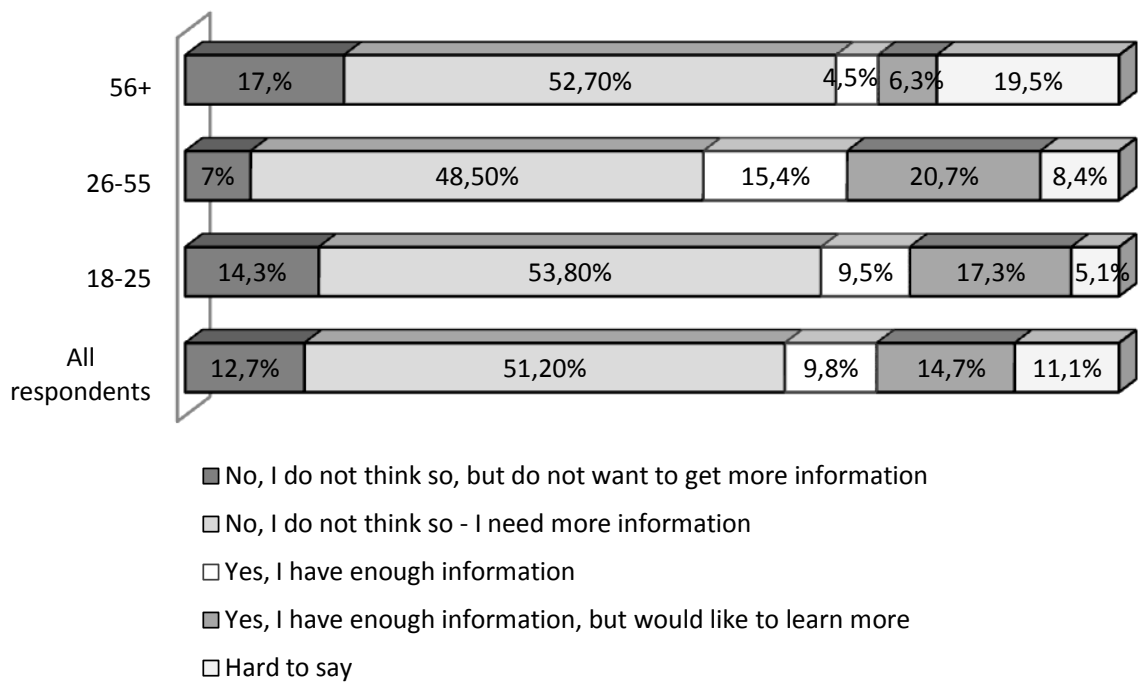

Figure 3. Shares of answers the question „Do you consider that you have sufficient information to protect your rights as a consumer of financial services?"

Source: S.M. Lobozynska, 2016, Report on the survey „,Protection of consumers in financial services in Ukraine", November, 1,500 questionnaires.

Consumers of all ages have expressed a desire to improve their financial literacy. The highest share of those who wish is in the age group 18-25-71.1\%, the lowest in the 56+ age group - 59\%. In the age group 26-55 the share of those who wish to increase their knowledge on the mechanism of consumer rights protection in the financial market is $-69.2 \%$.

In all age groups there is a priority belief that information about the mechanism of consumer rights protection in printed version should be provided by a financial institution when signing a contract for services (Fig. 4).

Also, according to the results of questionnaire we can conclude that all proposed channels for expansion of information were confirmed by respondents and will yield benefit in raising of financial literacy of society.

Figure 5 reflects the behaviour of consumers under condition of violation of their rights as consumers of financial services. 


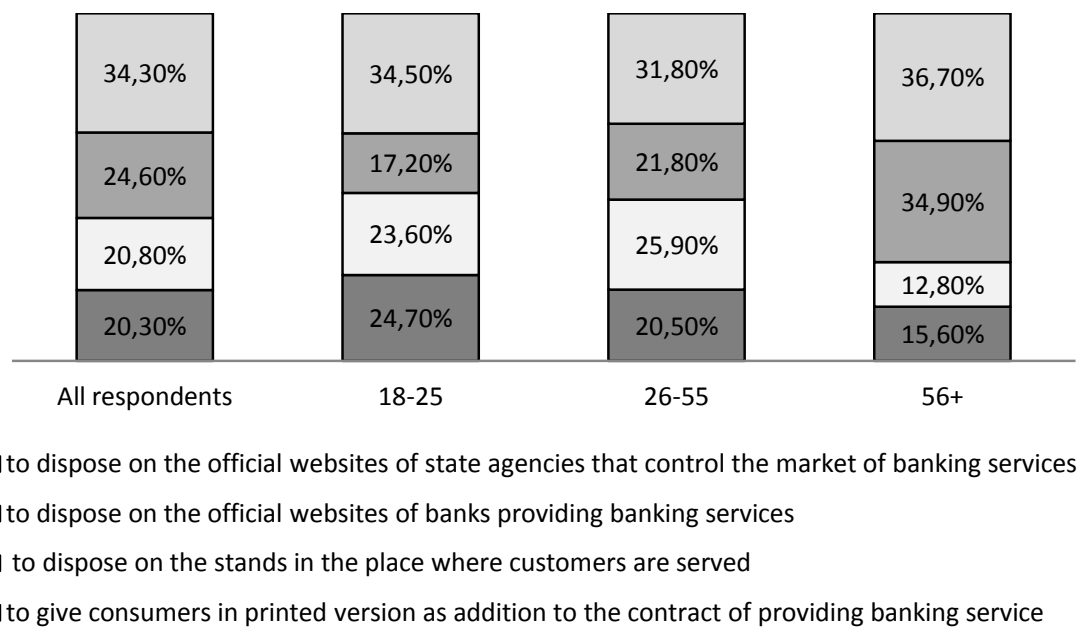

Figure 4. Shares of answer the question „The information about consumer rights it is necessary...”

Source: S.M. Lobozynska, 2016, Report on the survey „,Protection of consumers in financial services in Ukraine", November, 1,500 questionnaires.

There is a fact that cannot stay out of our attention that $32.9 \%$ of respondents take a passive stance on upholding their rights. This can be explained by the low level of confidence to the supervisory bodies of executive power and the judiciary, as well as low levels of their effectiveness. The largest proportion of respondents (32\%) considers it appropriate to make a complaint to the financial institution that provided the service and settle the conflict on the ground. This shows the importance of introducing in the structure of financial institutions the separate departments of consumer complaints. According to the results of questionnaire $21.8 \%$ of respondents consider that it is appropriate to apply to a competent authority responsible for consumer rights protection in financial services market. Overall, during 2016 the National Bank of Ukraine received 83,651 complaints of citizens $(27.96 \%$ concerned the relationship on credit agreements; $21.3 \%$ - the question of banking supervision, $13.5 \%$ - for deposit agreements relationships) [The data of arrival..., 2017]. The National Commission which provides state regulation of financial services markets in 2016 received 5539 appeals of citizens. By the nature of questions a significant proportion of complaints to the breaking of payment terms or reduction of the amount of insurance reimbursement, and also refusal to pay insurance reimbursement by insurance companies (76.3\% of total complaints) [Information of the National Commission..., 2017]. 


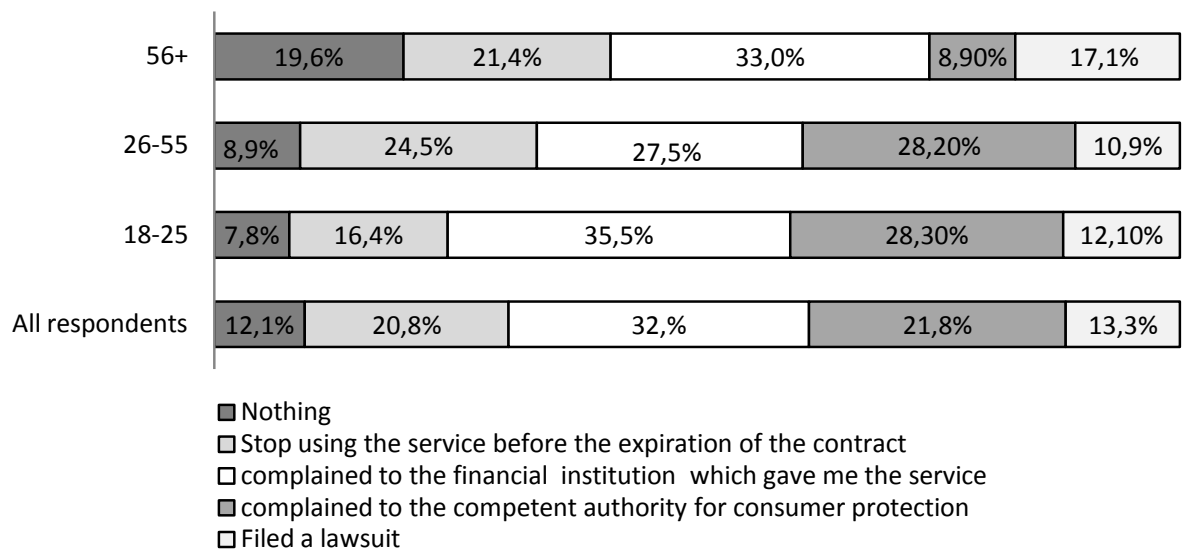

Figure 5. Shares of answers the question If your rights have been violated (or could be violated) by the financial institution, what you have done (or will do)?

Source: S.M. Lobozynska, 2016, Report on the survey „,Protection of consumers in financial services in Ukraine", November, 1,500 questionnaires.

In Ukraine the responsibility for rights protection of consumers of financial services market is assigned to several regulatory authorities. Under these conditions, consumers need to spend a lot of time finding out where to direct complaint and from whom to expect the solution to their problems. Therefore, in the nearest future the organizational and functional mechanism to protect the rights of consumers in the financial market of Ukraine should be improved, and by studying the international experience the pre-trial mechanisms of problem solutions of consumer protection should be actively implemented.

One of the aims of our research was to find out when consumers felt secure. Figure 6 shows the respondents answers which almost proportionally were divided into three areas: 1) the increase of the level of financial literacy $(33 \%), 2)$ the clear mechanism for resolving disputes (36.6\%). 3) the increasing number of public authorities that would ensure consumer protection in financial services market.

Financial education can potentially be an effective form of consumer protection (but cannot substitute for regulation). Building financial literacy is a long-term investment, whose effectiveness should be carefully measured and evaluated. World Bank Good Practices on Financial Consumer Protection recommend that a broad-based program of financial education and information is developed to increase the financial literacy of the population [Good Practices for Financial..., 2012]. A range of organizations, including those of the government, state agencies and non-government organizations, should be involved in developing and implementing the financial literacy program [Global Survey on Consumer Protection..., 2013]. 


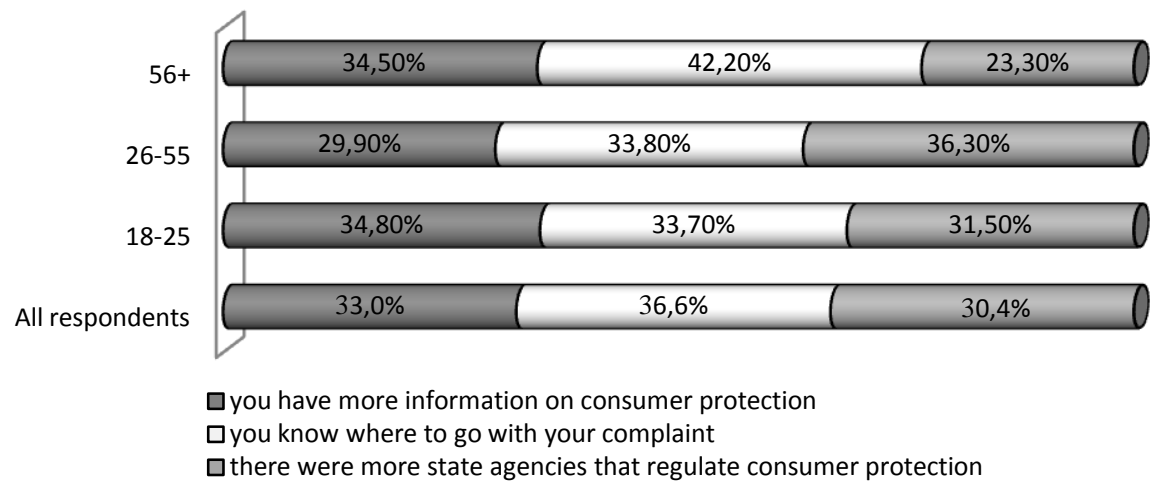

Figure 6. Shares of answers the question Will you be safer, if:...?

Soure: S.M. Lobozynska, 2016, Report on the survey „Protection of consumers in financial services in Ukraine", November, 1,500 questionnaires.

Ukrainians expect that the recommendations of the World Bank on implementation of financial literacy programs will be widely implemented in practice. The respondents believe programs on financial literacy for consumers should implement governmental authorities which regulate the financial services market and public organizations which are involved in consumer rights protection (Fig. 7).

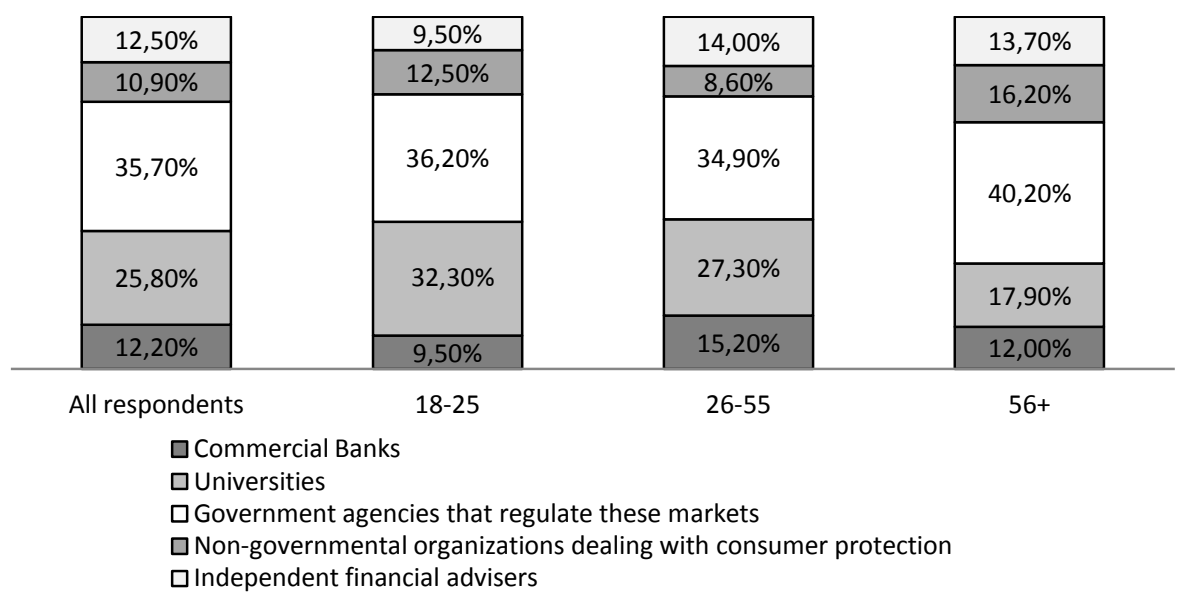

Figure 7. Shares of the answers the question „In your opinion, who should implement financial literacy programs for consumers?"

Source: S.M. Lobozynska, 2016, Report on the survey „Protection of consumers in financial services in Ukraine", November, 1,500 questionnaires. 
In Ukraine from 2009 began implemented programs aimed at improving of financial literacy and financial sector development in cooperation with the US Agency for International Development (USAID) [Bond 2010]. Taking into consideration the insufficient level of financial literacy of Ukrainian citizens and the thing that examined above program gave good results and the level of financial literacy grew, it was decided to introduce another program called FINREP-II. This is five-year program of financial sector development (from October 2012 to October 2017), funded by USAID and is designed to assist Ukraine in improving the stability of the financial sector and restoring confidence of people to financial markets [Financial Sector Development Program..., 2016].

However, the financial services markets in developing countries stay in unfavourable economic conditions for development what periodically generates the financial crisis. The population is not able to acquire knowledge of risk management in a crisis situation so quickly, that is why the level of financial literacy should by constantly deepened. Thus, according to research of Standard $\&$ Poor's conducted in cooperation with Gallup, the World Bank and the Global Research Centre of Financial Literacy (Global Financial Literacy Excellence Centre, GFLEC) at George Washington University (in November 2015) Ukraine in terms of financial literacy ranked 48th out of 144 countries in the world. The share of financially literate adult population is $40 \%$ [Ukraine and Russia in the ranking..., 2017]. Taking into account this, we believe that it is appropriate to develop a National strategy for consumer rights protection on financial services market and increasing of financial literacy of citizens (hereinafter - National strategy).

The main objectives of the National Strategy should be firstly the improvement of the legal framework in accordance with EU Directives and The High-level Principles on Financial Consumer Protection were endorsed by the G20 Finance Ministers and Central Bank Governors [The High-Level Principles..., 2012]. We consider it appropriate to develop and adopt the Law of Ukraine „On protection consumers' rights of financial services”.

An important component of the National Strategy should be the development of organizational and functional infrastructure of consumers rights protection, particularly it is necessarily to create specialized departments of consumers rights protection in the structure of each financial regulator, to form legislative the base for creating inside financial institutions the internal departments of analysis of the financial services quality and examination of complaints of consumers, to provide possible ways of implementation of out-of-court disputes resolution (out-of-court mechanism of resolving disputes (mediation, arbitration, financial ombudsman). 
The National strategies should form the task of raising the level of financial literacy. It is necessarily to provide periodic national financial literacy surveys. The surveys should review not just the ability of consumers to evaluate different financial products but also how consumers spend their paychecks. The surveys should review not just the ability of consumers to evaluate different financial products but also how consumers spend their paychecks and how much confidence they have that disputes with financial institutions will be resolved quickly and efficiently. The surveys should be broken down by age, gender, geographic area, socio-economic levels and years of formal schooling. Updated surveys can later determine if the financial education program has been effective and what additional consumer protection measures may be needed. The National Strategy should provide further analysis and financing of programs. The National surveys of consumer protection and financial literacy would be helpful for determination of future activities.

The implementation of the National Strategy for rights protection of consumer on financial services market and increase of financial literacy will contribute to financial stability and the growth of citizens welfare, will ensure the proper quality of financial services, will prevent the use of discriminatory practice to consumer of financial institutions, will increase the level of confidence of citizens regarding the protection of their interests and rights, will increase the confidence to the financial markets.

\section{CONCLUSIONS}

Thus, on the base of our research we can state that every fifth consumer of financial services faces violations of his rights. The most violations occur when using credit, deposit and payment services. Among services provided by nonbank financial institutions the most violations are recorded from the side of insurance companies on violation of terms of payment or decrease of the amount of insurance indemnity and also refusal to pay insurance compensation.

The empirical research has shown that a significant proportion $(71.1 \%)$ of financial services consumers realize the need to raise the level of their financial awareness. Thus every third respondent takes a passive position to protect his rights as consumer of financial services. The explanation for this is the low level of public confidence in financial regulators and the court system activities.

Consumers consider themselves protected under condition of increasing their literacy, availability of a clear mechanism to protect their rights, which, according to respondents' answers, should inform the financial institution which sells the financial service. We consider it appropriate for creating a simple and affordable mechanism for consumer rights protection in the structure of each 
financial regulator to create the appropriate department for consumer protection and to prepare legislation which should commit financial institutions to create divisions (departments) of quality of financial services and dealing with citizens complaints.

In order to protect consumers of financial services and improving financial literacy it is advisable to develop and adopt a National Strategy, which main task would be: improving the legal base of financial consumer protection), development of organizational and functional infrastructure of consumer rights protection, introduction of out-of-court mechanisms of disputes resolution, conducting national surveys of consumer protection level and implementation of programs to improve financial literacy for individual target audiences.

\section{REFERENCES}

Bond R., 2010, Financial literacy and awareness in Ukraine: Facts and Conclusions, [in:] R. Bond, A. Kutsenko, N. Lozitskaya. - K.: USAID FINREP, [electronic resource] http://www.uaib.com.ua.

Customer suitability in the retail sale of financial products and services, 2008, The Joint Forum. Bank for International Settlements April, [Web resource]. - URL: https://www.iosco.org/lib rary/pubdocs/pdf/IOSCOPD268.pdf

Financial Sector Development Program (USAID/FINREP-II), 2016, [Web resource] - URL: http://www.finrep.kiev.ua/structure/news_ua.php.

Good Practices for Financial Consumer Protection, 2012, World Bank, [Web resource] - URL: http://responsiblefinance.worldbank.org/ /media/GIAWB/FL/Documents/misc/Good-practicesfor-financial-consumerprotection.pdf.

Global Survey on Consumer Protection and Financial Literacy (Oversight frameworks and practices in 114 economies), 2013, World Bank, [Web resource] - URL: http://documents. worldbank.org/curated/en/775401468171251449/pdf.

Information of the National Commission for State Regulation of Financial Services Markets about the results of the work made with citizens complains, 2017, [Web resource] - URL: https://nfp.gov.ua/content/materiali.html).

Lobozynska S.M., 2016, Report on the survey „Protection of consumers of financial services in Ukraine", November, 1,500 questionnaires.

Radchuk A., 2017, The collapse of trust: what expect the banking system in 2017? [Web resource]. - URL: https: //www.slovoidilo.ua/2017/01/10/kolonka th/aleksandr-radchuk/finansy/kolapsdoviry-shho-ochikuye-bankivsku-systemu- v-2017-roczi.

Rutledge S.L., Annamalai N., Lester R., Symonds R.L., 2010, Good Practices for Consumer Protection and Financial Literacy in Europe and Central Asia: A Diagnostic Tool, [Web resource] - URL: http://siteresources.worldbank.org/INTECAREGTOPPRVSECDEV/Resources/ GoodPractices_August2010.pdf.

Rutledge S.L., 2010, Consumer Protection and Financial Literacy Lessons from Nine Country Studies, „Policy Research Working Paper”, 5326. The World Bank Europe and Central Asia Region Finance and Private Sector Department, June.

Statistics of DGF, 2017, [Web resource]. - URL: http://www.fg.gov.ua.htm. 
The data of arrival, character and status of fulfillment of complaints of citizens in 2016 year, 2016, National Bank of Ukraine, [Web resource] - URL: https://bank.gov.ua/control/uk/ publish/article?art_id=43401183\&cat_id=103156.

The High-level Principles on Financial Consumer Protection were endorsed by the G20 Finance Ministers and Central Bank Governors (G20/OECD Task Force on Financial Consumer Protection, „Update Report on the Work to Support the Implementation of the G20 High-Level Principles on Financial Consumer Protection", 2012, [Web resource] - URL: http://www.oecd.org/daf/fin/financial-education/G20EffectiveApproachesFCP.pdf.

Ukraine and Russia in the ranking of financial literacy are below Zimbabwe, 2017, [Web resource]. - URL: http://korrespondent.net.

2016th: political results - general national survey, 2016, [Web resource] - URL: http://dif.org.ua/article/2016-y-politichni-pidsumki-zagalnonatsionalne-opituvannya.

\section{PROBLEMY OCHRONY PRAW KONSUMENTÓW W SEKTORZE USŁUG FINANSOWYCH UKRAINY: BADANIE EMPIRYCZNE}

\section{Streszczenie}

Celem artykułu było przedstawienie ochrony konsumentów na rynku usług finansowych na Ukrainie. $W$ toku badań empirycznych, na podstawie informacji pozyskanych z kwestionariusza ankietowego, wypełnionego przez 1500 respondentów ustalono zakres działań podejmowanych przez niezadowolonych, z jakości usług finansowych konsumentów a także opisano charakter naruszeń ich praw. Ponadto, szczególną uwagę skupiono na identyfikacji poziomu wiedzy finansowej i poszukiwaniu skutecznych mechanizmów ochrony praw konsumentów. Z przeprowadzonych badań wynika, że uzasadniona jest konieczność opracowania i przyjęcia Narodowej Strategii ochrony praw konsumentów usług finansowych oraz zwiększenie wiedzy finansowej ludności.

Słowa kluczowe: ochrona praw konsumenta usług finansowych, wiedza finansowa, instytucje finansowe, mechanizm wstępnego rozwiązywania sporów, Narodowa Strategia. 